\title{
新しいスマートフォン依存尺度の開発
}

\author{
戸田 雅裕, 西尾 信宏, 竹下 達也 \\ 和歌山県立医科大学公衆衛生学教室
}

\section{Development of a New Scale for Gauging Smartphone Dependence}

\author{
Masahiro TODA, Nobuhiro NISHIO and Tatsuya TAKESHITA \\ Department of Public Health, Wakayama Medical University, Wakayama, Japan
}

\begin{abstract}
Objectives: We designed a scale to gauge smartphone dependence and assessed its reliability and validity.

Methods: A prototype self-rating smartphone-dependence scale was tested on 133 medical students who use smartphones more frequently than other devices to access web pages. Each response was scored on a Likert scale $(0,1,2,3)$, with higher scores indicating greater dependence. To select items for the final scale, exploratory factor analysis was conducted.

Results: On the basis of factor analysis results, we designed the Wakayama Smartphone-Dependence Scale (WSDS) comprising 21 items with 3 subscales: immersion in Internet communication; using a smartphone for extended periods of time and neglecting social obligations and other tasks; using a smartphone while doing something else and neglect of etiquette. Our analysis confirmed the validity of the different elements of the WSDS: the reliability coefficient (Cronbach's alpha) values of all subscales and total WSDS were from 0.79 to 0.83 and 0.88 , respectively.
\end{abstract}

Conclusions: These findings suggest that the WSDS is a useful tool for rating smartphone dependence.

Key words: smartphone（スマートフォン）, Wakayama Smartphone-Dependence Scale（WSDS）, reliability (信頼性), validity（妥当性）, medical students（医学生）

緒言

携帯電話の急速な普及, また日常生活への浸透に伴い, 依存や過剰使用といった影響が懸念されている。我々は, 携帯電話依存をテクノストレスの一種と捉え, 高リスク 群 / 要指導群をスクリーニングするための尺度である Mobile Phone Dependence Questionnaire（MPDQ）をいち 早く開発 (1), これまでにライフスタイルや性格行動様 式, あるいは抑らつ度といった個々人の持つ様々な特性 との関係について検討を加えてきた (2-4)。

一方, 携帯電話端末の高機能 / 多機能化はめざましく, とりわけ 2008 年に販売が開始されたスマートフォン（ス マホ）は通話機能を備えたパソコンとでも言うべきもの

受付 2015 年 2 月 2 日，受理 2015 年 3 月 10 日

Reprint requests to: Masahiro TODA, $\mathrm{PhD}$

Department of Public Health, Wakayama Medical University, 811-1 Kimiidera, Wakayama 641-8509, Japan

TEL: +81(73)441-0647, FAX: +81(73)448-0238

E-mail: mt@wakayama-med.ac.jp
であるが，端末契約数に占める割合は 2014 年 3 月末の 時点で 47.0\% に達して扣り, その普及速度も著しい(5)。 スマホは従来の携帯電話端末に比べ処理能力が高く, パ ソコン用ウェブサイトの閲覧も可能であることが大きな 特徵であり，その手軽さから 2013 年末現在，家庭内及 び家庭外に打けるインターネット接続手段のそれぞれ $31.7 \%$ 及び $43.4 \%$ を占めるに至っている $(6,7)$ 。このた め, 今後, スマホを介したインターネット依存症の増加 が強く予測され, 視力低下, 頸肩腕症候群, あるいは運 動不足による筋力低下といった身体への影響，抑うつや 攻撃性の出現といった精神面への影響，また生活りズム の乱れによる社会生活への支障や家族を含めた対人関係 の悪化といった社会性への影響が懸念される（8）。この ように携帯電話の概念は大きく変わりつつあり, MPDQ に変わる, より現状に即した新しい尺度を開発する必要 性が生じてきた。

諸外国に拉いてはスマホ依存を評価するための尺度が 考案, 実用化されているが $(9,10)$, 我が国独自の尺度 となると未だ確立されていないのが現状である。そこで, 
本研究ではスマホ依存に特化した評価尺度を作成し，そ の信頼性ならびに妥当性を検討した。

\section{方法}

\section{1. 質問紙の作成手順}

先述の MPDQ(1)，また Youngによる Internet Addiction Diagnostic Questionnaire (IADQ) (11) 等を参考に, ブレーンストーミング法 (12) によりスマホ使用に関す る質問項目の収集を行った。この作業を数回繰り返した 後, 最終的に 42 項目の質問が採択された。各質問項目 の回答形式は,「該当する」,「やや該当する」,「あまり 該当しない」,「全く該当しない」の 4 件法とし, それぞ れに $3 \sim 0$ 点の得点を与えた。いずれもスマホへの依存 が強い汪ど尺度得点が高くなるよう設定されている。

\section{2. 調査対象}

本研究は和歌山県立医科大学倫理委員会の承認を得 て, 平成 26 年 2 月〜 6 月に実施された。医学生 202 名 に対し，「携帯電話使用に関する質問票」と題された上 述のスマホ依存尺度 42 項目を含む無記名式の質問紙を 配布した。対象者には書面で協力を依頼し, 質問紙への 回答をもって同意を得たものとした。また，回収した質 問紙には任意の番号を付し，連結不可能匿名化とした。 196 名より回答を得, 有効回答 195 名（有効回答率 96.5\%）のらちスマホを所有している 184 名を解析対象 とした。

\section{3. 解析方法}

\section{（1）スマホ依存尺度の探索的因子分析}

スマホ所有者のらち，インターネットへの接続手段と して主にスマホを利用していると回答した 133 名（男性 82 名, 女性 51 名, 平均年齢 20.9 歳）を対象に, スマホ 依存尺度 42 項目について主因子法及びバリマックス回 転による探索的因子分析を行った。因子負荷量が 0.4 未 満の項目, 複数の因子に 0.4 以上の負荷量を示す項目, また上位 $2 つ の$ 因子負荷量の差が 0.1 未満の項目を削除 しながら因子分析を繰り返し, スマホ依存尺度の最終版 を完成させた $(12,13)$ 。

（2）スマホ依存尺度最終版の内的整合性の確認, 及び 確証的因子分析

スマホ依存尺度最終版の尺度全体及び各下位尺度につ いて Cronbach の $\alpha$ 係数を算出し, 質問項目の内的整合 性を評価した $(12,13)$ 。また，構造方程式モデリングを 用いた確証的因子分析により，構成概念妥当性を検討し た。モデル適合度の指標には, Good of Fit Index (GFI), Adjusted GFI (AGFI), Comparative Fit Index (CFI), 及 び Root Mean Square Error of Approximation（RMSEA）を 用い, GFI， AGFI，CFI が 0.9 以上，また RMSEA が 0.05 以下を適合基準とした（14）。

\section{（3）スマホ依存度の数値化，及び各種要因との関連性 の検討}

スマホ依存尺度最終版の妥当性をより多面的に評価す るため, 各質問項目の得点を加算することにより数值化 したスマホ依存度について，1日の通話時間，メール利 用時間，及びウェブ閲覧時間との基準関連妥当性を検討 したが，その際，各時間の正規性が Kolmogorov-Smirnov 検定により棄却された為, Spearmanの順位相関係数を 用い解析を行った。また, Student- $t$ 検定により,インター ネットへの接続手段として主にスマホ以外の端末を利用 していると回答した群との依存度得点の比較を行った。

以上の統計解析については，構造方程式モデリングを 用いた解析にはA Amos 4.0 を, その他の解析にはSPSS $11.5 \mathrm{~J}$ を用いた。いずれの検定に抢いても統計学的有意 水準は $p<0.05$ に設定した。

\section{結果}

\section{（1）スマホ依存尺度の探索的因子分析}

スマホ依存尺度の因子分析では，スクリー法により5 因子構造が妥当であると判断した。先に述べた基準によ り項目を削除し，スクリープロットを確認しながら因子 分析を繰り返した結果，最終的に 21 項目が抽出された （表 1)。各因子に高い負荷量を示した項目群より，第 1 因子は「ネットコミュニケーションへの没頭」を，第 2 因子は「スマホの優先」を, 第 3 因子は「マナーの軽視」 を, 第 4 因子は「ながらスマホ」を, また第 5 因子は「長 時間の通話」をそれぞれ反映する因子であると考えられ た。確認された下位概念の類似性を勘案し，第 2 因子と 第 5 因子，また第 3 因子と第 4 因子を合わせて新たな下 位尺度「スマホの優先と長時間使用」及び「『ながらスマ ホ』とマナーの軽視」とし，スマホ依存尺度 Wakayama Smartphone Dependence Scale（WSDS）を完成させた。

\section{（2）WSDS の内的整合性の確認，及び確証的因子分析}

新たに設定した下位尺度について構成概念妥当性を検 討するため図 1 に示す因果モデルを構築し，データへの 適合度を共分散構造分析により検討した結果, GFI= 0.983, $\mathrm{AGFI}=0.942, \mathrm{CFI}=0.997$ ，及び $\mathrm{RMSEA}=0.027$ であった。また, 3 つの下位尺度の信頼性係数（Cronbach の $\alpha$ 係数) はそれ表れ0.83（「ネットコミュニケーショ ンへの没頭」)，0.79 (「スマホの優先と長時間使用」), 及び 0.79 (「『ながらスマホ』とマナーの軽視」) であり, 尺度全体では 0.88 であった。

\section{（3）WSDS 得点と各種要因との関連性の検討}

因子分析対象群の WSDS 総得点，及び各下位尺度得 点を表 2 に示す。Kolmogorov-Smirnov 検定により, こ れら全ての得点分布について正規性が確認された。また, 因子分析の対象としなかった群，即ちインターネットへ 


\begin{tabular}{|c|c|c|c|c|c|}
\hline \multirow{2}{*}{ 質問項目 } & \multicolumn{5}{|c|}{ 因子負荷量 } \\
\hline & 第 1 因子 & 第 2 因子 & 第 3 因子 & 第 4 因子 & 第 5 因子 \\
\hline リアルの会話よりも，スマホでのコミュニケーションの方が楽しい & .790 & .089 & .132 & -.036 & .048 \\
\hline スマホ以外，特に趣味がない & .730 & .124 & .057 & -.046 & -.030 \\
\hline $\begin{array}{l}\text { 自分の送ったメールや書き込みに対する返信が遅いことが原因で, 相手と } \\
\text { トラブルになることがある }\end{array}$ & .686 & -.060 & .203 & -.155 & .160 \\
\hline スマホをしている最中に話しかけられると，イラッとすることがある & .677 & .253 & .232 & -.021 & .159 \\
\hline スマホがないと, 友人とコミュニケーションがとりにくい & .565 & .206 & .186 & .116 & .116 \\
\hline 電話や直接話すより，メールの方が本音を言える & .543 & .094 & -.020 & .255 & -.020 \\
\hline 現実から逃避するためにスマホを使らことがある & .490 & .198 & -.061 & .141 & .126 \\
\hline スマホに熱中するあまり，学業や仕事に支障をきたすことがある & .119 & .756 & .316 & .060 & .080 \\
\hline スマホに熱中するあまり, その日の予定が狂ってしまらことがある & .336 & .712 & .229 & .037 & -.018 \\
\hline 他にしなければならないことがあるのに，スマホをしてしまらことがある & .035 & .709 & .020 & .261 & .114 \\
\hline スマホのせいで, 夜更かしをしてしまったり, 寝不足になったりすることがある & .228 & .621 & .134 & .260 & .188 \\
\hline スマホを使う時間がだんだん長くなっていると感じる & .177 & .502 & .070 & .262 & .025 \\
\hline 他人との会話中にスマホを使うことがある & .157 & .138 & .749 & .283 & .157 \\
\hline 食事中にスマホを使らことがある & .131 & .198 & .661 & .176 & .021 \\
\hline 人と二人でいるときにスマホを使らことがある & .124 & .137 & .635 & .135 & .078 \\
\hline 電車やバスの中でスマホを使うことがある & -.063 & .132 & .041 & .618 & -.127 \\
\hline 授業中や仕事中にスマホを使らことがある & .064 & .130 & .304 & .571 & .124 \\
\hline 歩きながらスマホを使らことがある & .143 & .190 & .286 & .547 & .244 \\
\hline 電話やメールの着信がないか，無意識にスマホを見ることがある & .014 & .209 & .166 & .415 & .069 \\
\hline 夜遅くてもスマホで電話をしてしまう & .053 & .113 & .119 & .064 & .825 \\
\hline 1 日に 1 時間以上，スマホで電話をする & .355 & .116 & .098 & .044 & .504 \\
\hline
\end{tabular}

第 1 因子「ネットコミュニケーションへの没頭」, 第 2 因子「スマホの優先」, 第 3 因子「マナーの軽視」, 第 4 因子「ながらスマホ」, 第 5 因子「長時間の通話」

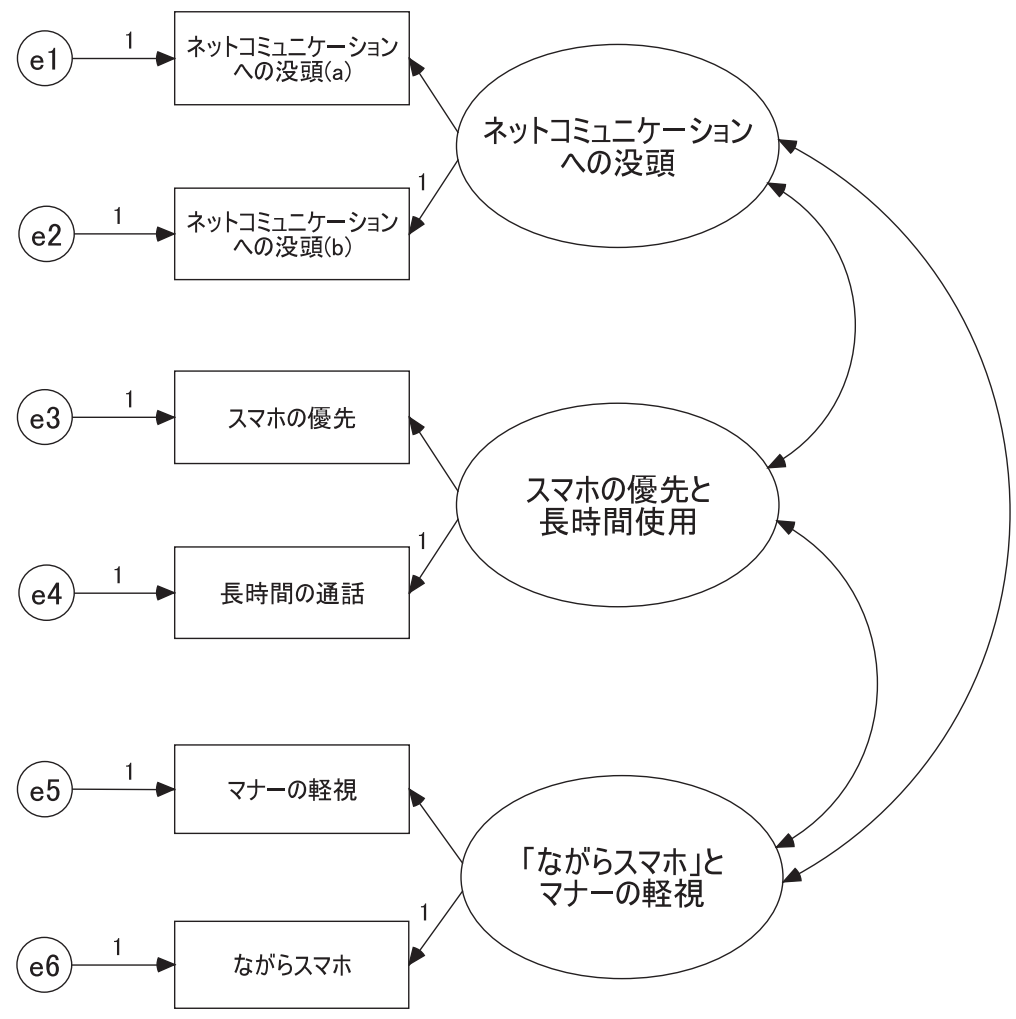

図 1 Wakayama Smartphone Dependence Scale (WSDS) の因子構造モデル 
表 2 Wakayama Smartphone Dependence Scale (WSDS) 総得点, 及び各下位尺度得点

\begin{tabular}{lcc}
\hline & \multicolumn{2}{c}{ インターネットーの主な接続手段 } \\
\cline { 2 - 3 } & $\begin{array}{c}\text { スマホ } \\
(\mathrm{n}=133)\end{array}$ & $\begin{array}{c}\text { スマホ以外の端末 } \\
(\mathrm{n}=51)\end{array}$ \\
\hline 総得点 & $29.5 \pm 9.2^{* *}$ & $21.6 \pm 8.7$ \\
下位尺度得点 & & \\
ネットコミュニケーションへの没頭 & $5.8 \pm 4.0^{*}$ & $4.1 \pm 3.0$ \\
スマホの優先と長時間使用 & $9.6 \pm 4.0^{* *}$ & $6.7 \pm 4.0$ \\
「ながらスマホ」とマナーの軽視 & $14.1 \pm 3.7^{* *}$ & $10.9 \pm 3.7$ \\
\hline
\end{tabular}

†因子分析対象群

值は平均土標準偏差

$* p<0.01, \quad * * p<0.001 （$ Student $-t$ 検定による「スマホ以外の端末」群との比較）

表 3 Wakayama Smartphone Dependence Scale (WSDS) 得点と 1 日の通話時間, メール 利用時間, 及びウェブ閲覧時間との関係 $(n=133)$

\begin{tabular}{lccc}
\hline & 通話時間 & メール利用時間 & ウェブ閲覧時間 \\
\hline 総得点 & .01 & $.18^{*}$ & $.34^{* *}$ \\
下位尺度得点 & & & $.20^{*}$ \\
$\quad$ ネットコミュニケーションヘの没頭 & .06 & .11 & .12 \\
スマホの優先と長時間使用 & .16 & .11 & $.32^{* *}$ \\
「ながらスマホ」とマナーの軽視 & -.15 & & .11 \\
\hline
\end{tabular}

值はSpearman の順位相関係数

$* p<0.05, \quad * * p<0.01$

の接続手段として主にスマホ以外の端末を利用している スマホ所有者との比較では, 全ての下位尺度に扮いて因 子分析対象群で有意に高い得点が認められ, 総得点につ いても有意に高かった。

次に, 因子分析対象群の WSDS 得点と 1 日の通話時間, メール利用時間，及びウェブ閲覧時間との関係を表 3 に 示す。「ネットコミュニケーションへの没頭」とメール 利用時間，また「スマホの優先と長時間使用」，「『なが らスマホ』とマナーの軽視」とウェブ閲覧時間との間に 有意な相関が認められ, WSDS 総得点はメール利用時間 及びウェブ閲覧時間双方と有意な相関を示した。

\section{考察}

今回の調査では, 有効回答 195 名のらちスマホ所有者 は 184 名であり，スマホ所有率は $94.4 \%$ であった。こ の数字は総務省により発表された平成 25 年末に打ける スマホ世帯保有率 $62.6 \%$ に比べ高くなって拉り（7）, 特 に若年層に打けるスマホ普及率の高さが示唆された。

探索的因子分析では 5 因子 21 項目が抽出されたが, 確認されたスマホ依存を構成する下位概念の類似性を勘 案し項目数が同一の 3 つの下位尺度, 即ち「ネットコミュ ニケーションへの没頭」,「スマホの優先と長時間使用」, 及び「『ながらスマホ』とマナーの軽視」に再編したこ とで，下位尺度間の得点比較が容易になる等，より有用 性の高い尺度に仕上がったと考えられる。この下位尺度 モデルについては確証的因子分析によりデータへの良好
な適合性が認められ, WSDS の構成概念妥当性が検証さ れた。また信頼性係数 (Cronbachの $\alpha$ 係数) については, $3 つ$ の位尺度で $0.79 \sim 0.83$, 尺度全体では 0.88 であり, WSDS の高い内部一貫性が確認された。

WSDS 各下位尺度得点と 1 日の通話時間, メール利用 時間，及びウェブ閲覧時間との関係を調査したところ， 「ネットコミュニケーションへの没頭」は代表的なネッ トコミュニケーション手段であるメールの利用時間と有 意な相関を示した $(\rho=0.20, p<0.05)$ 。ネットコミュニ ケーション手段については, 近年, 特に若年層に掞いて メールからソーシャルメディアに移行しつつあることが 報告されている $(15)$ 。今回の調査で, 「ネットコミュニ ケーションへの没頭」はウェブ閲覧時間との間に有意な 相関を示さなかったが，ウェブ閲覧時間についてさらに 詳細に調査したところ, 代表的なソーシャル・ネットワー キング・サービス（SNS）である LINE 及び Twitter の合 計利用時間との間に有意な相関が認められた $(\rho=0.30$, $p<0.01)$ 。

一方,「スマホの優先と長時間使用」 $(\rho=0.32, p<0.01)$, 及び「『ながらスマホ』とマナーの軽視」 $(\rho=0.33, p<0.01)$ はウェブ閲覧時間と有意な相関を示した。特に若年層に ついては，通話やメールに比ベ，ソーシャルメディアを 中心とするウェブの閲覧に最も多く時間を費やしている ことが報告されて抢り（15），これは我々の結果を支持 するものとなっている。尚,「スマホの優先と長時間使用」 には通話に関する質問項目も含まれて扣り, 今回の調査 では通話時間との間に有意な相関は認められなかったも 
のの, 一定の傾向が認められた $(\rho=0.16, p=0.08)$ 。さら に，インターネットへの主な接続手段としてスマホを利 用している群とスマホ以外の端末を利用している群との 比較では，WSDS 得点がスマホ利用形態 / 頻度に大きく 影響されることも併せて確認され，これらの所見は何れ も WSDS の妥当性を裏付忷ものであると考えられる。

以上，本研究ではスマホ依存を評価するための新しい 尺度WSDSを開発し，その信頼性ならびに妥当性を確認 した。今後は対象集団を拡大し，ライフスタイルや抑らつ 度等さまざまな要因との関連性を検討することで，スマ ホ依存の発症機序, またスマホ依存に起因し得る健康影 響を解明すると共に，それらの予防策を構築していきた いと考えている。加えて, 同尺度をより有用なものとす るため, スマホ依存高リスク群/要指導群をスクリーニン グするための適切なカットオフ值の検討が課題である。

\section{利益相反なし}

\section{文献}

(1) 戸田雅裕, 門田和之, 久保和毅, 森本兼鼌. 女子大学 生を対象とした携帯電話依存傾向に関する調査. 日本 衛生学雑誌 2004;59:383-386.

( 2 ) Toda M, Monden K, Kubo K, Morimoto K. Mobile phone dependence and health-related lifestyle of university students. Soc Behav Pers 2006;34:1277-1284.

(3) Ezoe S, Toda M, Yoshimura K, Naritomi A, Den R, Morimoto K. Relationships of personality and lifestyle with mobile phone dependence among female nursing students.
Soc Behav Pers 2009;37:231-238.

( 4 ) Toda M, Ezoe S. Multifactorial study of mobile phone dependence in medical students: relationship to health-related lifestyle, Type A behavior, and depressive state. Open J Prev Med 2013;3:99-103.

( 5 ) http://www.m2ri.jp/newsreleases/main.php?id $=010120140423500(2015.2 .26)$

( 6 ) http://www.soumu.go.jp/main_sosiki/joho_tsusin/d_faq/ faq01.html (2015.2.26)

( 7 ) http://www.soumu.go.jp/johotsusintokei/statistics/data/ 140627_1.pdf(2015.2.26)

（8）樋口 進. ネット依存症. 東京 : PHP 研究所，2013.

( 9 ) Kwon M, Lee JY, Won WY, Park JW, Min JA, Hahn C, $\mathrm{Gu}$ X, Choi JH, Kim DJ. Development and validation of a smartphone addiction scale (SAS). PLoS One 2013; 8: e56936.

(10) Lin YH, Chang LR, Lee YH, Tseng HW, Kuo TB, Chen $\mathrm{SH}$. Development and validation of the Smartphone Addiction Inventory (SPAI). PLoS One 2014; 9: e98312.

(11) Young KS. Internet addiction: the emergence of a new clinical disorder. Cyberpsychol Behav 1998;1:237-244.

（12）菅原健介. 心理尺度の作成過程. 堀 洋道, 山本真理 子，松井 豊 (編)，心理尺度ファイル一人間と社会 を測る一。東京 : 垣内出版, 1994, 637-652.

（13）EG カーマイン， RA ッェラー（水野欽司，野嶋栄一 郎訳)。テストの信頼性と妥当性. 東京: 朝倉書店, 1983.

（14）山本嘉一郎. 共分散構造分析とその適用. 山本嘉一郎, 小野寺孝義 (編)，Amos による共分散構造分析と解析 事例（第 2 版）。京都：ナカニシヤ出版，2002,1-22.

(15) http://www.soumu.go.jp/iicp/chousakenkyu/data/research/ survey/telecom/2014/h25mediariyou_3report.pdf(2015.2.26)

付録 Wakayama Smartphone Dependence Scale: WSDS

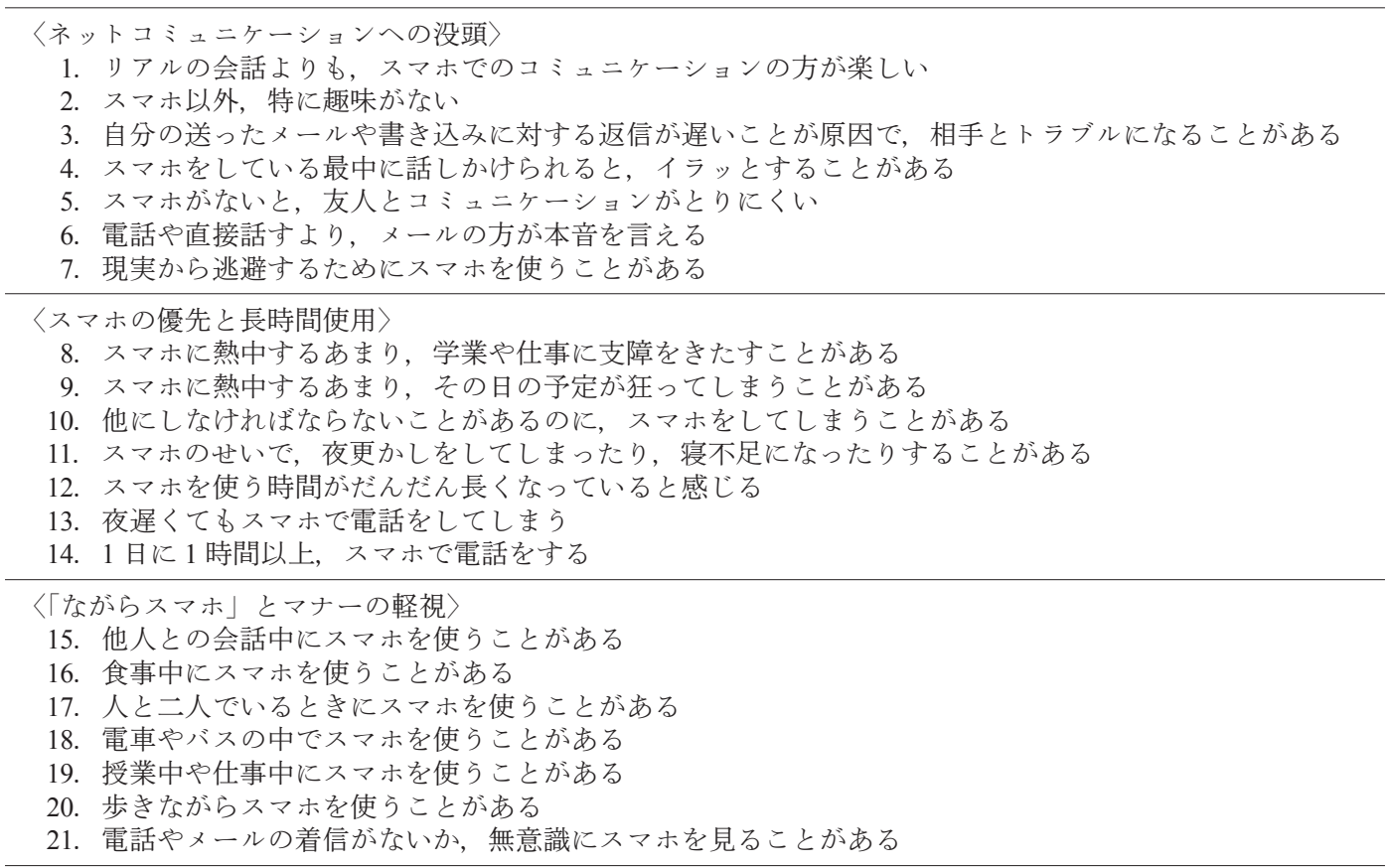

各質問項目の回答形式は「該当する (3 点)」, 「やや該当する (2 点) 」, 「あまり該当しない (1 点)」,「全く該当 しない $(0$ 点 $) 」 の 4$ 件法とし，得点の加算により各下位尺度得点，及び WSDS 総得点を算出する。 